\title{
A New Start? Negotiations of age and chrononormativity by older apprentices in England.
}

\section{Introduction}

In most countries, apprenticeships are still conceived as models of learning for young people, those in their first transition from full-time education to work (Fuller and Unwin 2013; Rauner and Smith 2010). Although the length of this transition has progressively been extending within Western societies, public perception is that apprentices are most commonly early school leavers, aged between 16 and 18 . However, since 2005, England has been challenging popular understandings by providing government funding for 'adult apprenticeships': people aged 19 and above, and with no upper age limit. The only other country with such a scheme is Australia (Karmel 2006). The latest official figures reveal that, in England, apprenticeship has become an 'adult' programme: 74 percent of apprentices in England are aged 19 and over, with 42 percent aged 25 and over (SFA/BIS 2016) and some 3,410 aged 60 plus (Gov,UK 2016i). It would appear, therefore, that a significant disjuncture exists between the imagined age and identity of an apprentice and the actual constitution of the apprenticeship workforce.

This paper aims to examine how this disparity impacts on the experience of apprenticeship in older age. Whilst there is a substantial and long-standing body of multi-disciplinary and international research on apprenticeship (see inter alia Ainley and Rainbird 1999; Fuller and Unwin 2013), the clear majority focuses on the younger age group. Very little is known about the phenomenon of 'adult apprenticeship' and what it may mean to retrain at an older age with experience and occupational expertise, as opposed to being young and more novice. With society 
and its institutions dominated by powerful discourses of 'chrononormativity' (Freeman 2010), temporal norms which benchmark the 'right time' for lifecourse and career intersections, research on ageing informs us that 'deviating from social clocks' (Barrett 2005: 166) can impact negatively on individuals' senses of self, peer relations and experiences of transitions as well as the potential for age discrimination (Chou and Choi 2011; Martin et al 2014). At the same time, alternative and competing discourses on 'productive ageing' argue that working in older age is beneficial for (economic) well-being. Against this contradictory discursive landscape, what are the motivations, benefits and challenges of training 'off-time'? And how is 'older age' experienced, understood and managed by both organisations and apprentices?

This paper explores these questions by drawing on a new study conducted with older apprentices and their employers in a range of occupational contexts in England. To contextualise the study, we commence with a brief policy overview before outlining the conceptual framework. This draws on Elizabeth Freeman's (2010) temporalities approach to consider how the social patternings of time exert a potent influence on understandings of age-normativity. Our analysis of our findings reveal that both organisations and the apprentices themselves are imbued by powerful discourses of 'chrononormativity'. Challenging this required careful negotiation of age by the older apprentices in our sample. However, our study also shows that many older people receiving multiple positive benefits from retraining in terms of motivation, pay and social relationships. We conclude that, if apprenticeships are to succeed fully in offering a positive choice for older people, organisations and economies, fundamental changes may need to be made to the internal logics of age and ageing within contemporary workplaces. These 
conclusions are not only important for the English context, but have broader resonance for other economies considering expanding their apprenticeship and training programmes to older workers.

\section{Policy Background}

There are strong policy drivers underpinning the expansion of apprenticeships across the age groups in England. Perennial concerns about the impact of skill levels and shortages on the UK's international economic competitiveness, productivity and social mobility have led successive governments to lift age limits on and increase funding to support apprenticeships (DfES 2003; Fuller et al 2015). It must be remembered, however, that this has been done within the context of the UK's highly flexible labour market and voluntarist approach to workforce development (see inter alia, Keep et al 2006). Nevertheless, since the late 1970s, governments have sought to boost the UK's standing in international league tables measuring the numbers and levels of qualifications in the adult population (Leitch 2006). A key mechanism has been the mandatory requirement for all participants in government-funded youth and adult training programmes to attain a competence-based national vocational qualification. This has enabled individuals in employment to be 'converted' into becoming an apprentice or trainee so their existing competencies can be assessed and certificated (Fuller and Unwin 2009). Whilst some additional off-the-job training may be required to enable an individual to meet all the competence requirements, and participants must also pass tests in literacy, numeracy and Information Technology (IT), it is possible to complete an 'apprenticeship' without having developed significant new skills. 
In cases where the government's apprenticeship programme is used primarily to accredit the prior learning of existing employees, it can be conceived as a model of assessment rather than as a model for learning. In cases where the programme is used in the traditionally understood sense to support an individual's development from novice to occupational expert through training in and outside the workplace, apprenticeship can be conceived as primarily a model of learning. This latter model is typically associated with an employer's recruitment of apprentices as newcomers (often young people) to the workplace and their subsequent training and development over a considerable period of time. The point we would highlight here is that under the government's scheme, both models are permissible (see Fuller and Unwin 2003 for further details of the policy background).

The importance of this qualification-led approach to skills policy in the UK cannot be underestimated. It problematizes standard economic assumptions about why employers might or might not invest in training. Over the past 30 years, a 'skills industry' has developed as government funding for programmes including apprenticeship has been channelled through private and public sector training providers. Employers are incentivised financially by the Government to recruit apprentices or 'convert' existing employees in three ways: (i) organisations with less than 50 employees receive a $£ 1500$ grant per apprentice aged 16-18; (ii) the costs of the training and assessment necessary to achieve the mandatory qualifications are met by government; and (iii) the national apprenticeship wage rate is set below both the National Living Wage (NLW) for people aged 25 and over and the National Minimum Wage for those under 25 . The apprentice wage rate (currently £3.30 per hour) applies to all apprentices regardless of age during the first year of their apprenticeship. Any apprentice over 25 whose apprenticeship extended beyond one 
year are then paid the NLW (currently $£ 7.20$ per hour). Adherence to labour market voluntarism means that apprentice pay rates vary considerably across the economy, as do the quality of apprenticeship training and the active involvement of employers. In this paper, we include research data that reflects this variability from organisations who have 'converted' some of their existing employees into apprenticeships of high quality to those offering very little new training, as well as adults recruited into newly created apprenticeships.

Against this incentivised background, some larger employers, particularly in the care, engineering and IT sectors, where real imperatives exist for retraining, upskilling and developing capacity, have been keen to offer apprenticeships to their older employees (Fuller et al 2015; McNair, Maltby and Nettleship 2007). However, it is rather by default that apprenticeship policy in England has echoed the escalation of 'productive ageing' technologies which are emerging within neoliberal economies more broadly due to the contraction of labour forces and heightened pressures on welfare benefits due to 'global greying' (Boudiny 2013; Moulaert and Biggs 2012)

\section{Conceptualising Age, Identity and Work}

In recent years, research has demonstrated that the conceptualisation of age, work and retraining within both neoliberal policy-making and organisational settings is dominated by two powerful yet competing discourses. Albeit in oppositional terms, both discourses encapsulate what Freeman (2010) describes as 'chronobiopolitics': the use of time by societies to manage their populations. Personal histories are made legible through state-sponsored timelines which serve national economic interests by framing lives as chronological sequences of 'productive' moments; normalizing the 'prime' age at which to, for example, train or attend higher education, 
start a career, attain promotion, or think about 'winding down' in terms of labour market participation (Field, Burke and Cooper 2013; Fuller, Heath and Johnston 2011).

A legacy of industrialisation, the dominant discourse of training and work is framed through a linear temporality of chronological age. Neatly demonstrated by the OECD's (2013: 132) classification of the labour force into three age groups:15-24 year olds as 'recent labour market entrants'; 25-54 year olds as in 'the prime of their working lives'; and 55-64 year olds as 'those who have passed the peak of their career and are approaching retirement'), chronometric categorisations position 'older' workers in terms of impending decline. In practice, the actual age to be considered 'old' is highly variable, contingent on national, occupational and gendered factors (Radl 2012; Unwin et al 2015). In some occupations, this might be late 30s and in others mid-50s (Gulette 2004). However, at a particular point in the lifecourse, a range of stereotypes come to frame workers as 'over the hill': 'too old and inflexible to learn new skills and keep pace with the demands of modern organisation' (Thomas et al 2014: 1573). Ageing is equated with lower levels of motivation and enthusiasm to participate in training and career development, resistance to change, poor performance and IT skills and increased sickness (Aubert, Caroli and Roger 2006; Lyon and Glover 1998; $\mathrm{Ng}$ and Feldman 2012). Despite strong evidence to the contrary (Loretto, Vickerstaff and White 2007; Lorreto and White 2006), research demonstrates how these essentialisms may serve to construct ageing workers as a 'risky project' (Ainsworth and Hardy 2008), regulating opportunities and subjectivities available to them (Gulette 2004). Impacting particularly negatively on women (Hodges 2012; Moore 2009; Zanoni 2011), ageing workers face a 'grey ceiling'; 'careers plateau and their skills become obsolescent' (Thomas et al 2014:1573). 
In some contradistinction to this, however, Western governments are also increasingly deploying an alternative discourse of 'productive ageing', emphasising self-reliance and continual self-monitoring over the lifecourse to sustain a lifelong contribution to work and work-like activities (Moulaert and Biggs 2012). A sub-set of a broader set of discourses on 'active ageing' aiming to 'enhance quality of life as people age' (Walker and Maltby 2012; WHO 2002:12;), productive ageing argues that extending working life helps buttress the volatility and risks inherent in contemporary societies (Sennett 2006; Standing 2011). This discourse thus takes a conceptual shift to argue 'if it is possible for older people to work, they should do so' (Ranzijn 2010: 717; Rudman 2006). Removal of the statutory retirement age and changes to pensions and benefit systems are key technologies to establish the new political rationality of lifelong productivity, supported by rights-driven agendas such as improvements in age discrimination legislation and, as discussed above, funded support for ongoing workplace training (Boudiny 2013, Field, Burke and Cooper 2013).

Rather than positioning ageing workers in a grey zone of limited futures therefore, the productive ageing discourse repositions boundaries between work and ageing as porous and malleable. And indeed, evidence suggests that some organisations are embracing older workers as a new employment pool to recruit into skills shortages and/or as aesthetic labour by which to stage products and services (Ainsworth and Cutcher 2008; Foweraker and Cutcher 2015). Furthermore, older workers may themselves seize opportunities to retain productivity and realise personal goals through 'encore careers' or self-employment (Simpson, Richardson and Zorn 2012). Research on intergenerational learning offers important new understandings of the potentials of an aging workforce, revealing how substantial benefits may be delivered 
to both individuals and organisations (Ropes and Ypsilanti 2012; Tempest 2003;). Older participants enjoyed feeling valued through mentoring and gained satisfaction from 'giving back' (Ropes 2013), and gaining new skills, perhaps via 'reverse mentoring' (Baily 2009). However, what we know less about is the experience of 'going back to the beginning' and retraining in a different occupation alongside younger new entrants. We know that in theory increasing flexibility in transitions between education/training and work will lead to plasticity in age-specific norms and expectations, but (how) is this experienced in practice?

What is particularly germane here is how both discourses highlight that ageing is a social process, flexibly manufactured and given meaning by society and its institutions for economic ends. Thus while on the face of it the two discourses offer paradoxical understandings and performances of ageing and work, in fact they rest on a shared temporality, which Freeman terms 'chrononormativity', whereby work and its institutions determine the ways we understand (how to) age. In other words, 'institutional forces come to seem like somatic facts' (2010:2): work, and its 'interlocking temporal schemes' become so implanted into our lives that 'corporations and nation states...adjust the pace of living in the places and people they take on' (Freeman 2010: 2). Chrononormativity describes how, as individuals, we become positioned by a normative 'logic' of time which is 'modern', industrialised and highly orchestrated to ensure maximum productivity (Odih 1999). This is a linear temporality of consequential sequence, by which 'the mundane workings of everyday life' are ordered and experienced (Freeman 2010). Yet while chrononormativity dominates Western lives, dictating what should be done when, it co-exists alongside alternative, non-chronological and non-normative forms of temporality (Odih 1999; Amin 2015). Within the lived, embodied and often messy realities of actual lives, time 
is not always linear and bound by the clock time, but may be 'out of joint': visible in the forms of interruption to the smoothed temporal orders described above. Freeman identifies these as hiccups in sequential time, or moments where the historical past disrupt the present and infuse the future through, for example: domestic time (the never-ending repetitive demands of household chores and family care); and bodily time (rhythms of bodies and emotions). The multiplicity of time means that different aspects and conceptual understandings of time can be simultaneously experienced and constituted (Adam 1995), with 'the smooth production of ...organisational life' (Riach and Kelly 2015: 288) co-existing, and perhaps being undermined by, other dechronologicised times, such as caring or creative pursuits (Halford and Leonard 2006). These alternative temporalities confront the logic of forward movement and offer different understandings of the lifecourse to the policy-driven discourses described above. Rather than a relentless 'forward march' of maximum productivity, it is co-constituted through asynchrony, fractures and reversals (Adam 1995; Freeman 2010).

Thus, as Foucault (1980) argued, while institutional discourses offer powerful knowledges about 'approved ways to be' (Baxter 2003:26), individuals are not only 'inert or consenting target[s]; they are always also the elements of its articulation' (Foucault 1980:87). In this paper, we conceptualise identities and senses of self as continually emerging through such articulations. It is through our performances and speech, drawing as they do on a range of social and discursive resources associated with age, gender, race and class (Halford and Leonard 2006), that social and occupational identities are negotiated. In other words, whilst we are subjected to discursive possibilities of how we can be as, for example, aged/gendered individuals, it is through our individualised enactment of discourses or 'narrative repertoires' that 
our own identities as aged and gendered individuals are constructed and reconstructed (Ibarra and Barbelescu 2010). Individual agency thus allows for a degree of choice and/or creative transgression in the construction of identities. whereby dominant discourses may be adapted to, negotiated or resisted (Baxter 2003; Riach and Cutcher 2014).

Ibarra and Barbelescu (2010) have demonstrated how 'macro work transitions' such as moves within or between jobs and organisations, require particular forms of negotiation or 'identity work' to fashion a 'culturally appropriate self' in the new context. This is especially demanded when the new work identity is discontinuous, or deviates from socially scripted or highly institutionalised trajectories. 'Because new roles require new skills, behaviours, attitudes and patterns of interpersonal behaviour, they may produce fundamental changes in an individual's self-definitions' (Ibarra and Barbelescu 2010: 138). In this context, identity work, typically through self-narratives or stories, enables connections to be constructed between old and new identities. Exploring the detail of people's narratives thus enables better understanding of the work involved in transitions, and how new identities may be negotiated.

The theoretical framework of this paper draws together these three elements: discourses of chrononormativity, alternative temporalities and identity work. The dynamic interaction of these elements will help us tease out the ways in which older apprentices negotiate the dominant meanings of older age.

\section{The Study and Methods}

Our study, commencing in 2013, aimed to develop understanding of the diversity of organisations' and adult apprentices' perceptions and experiences through in-depth 
qualitative research. Given the segregated nature of the labour market, apprenticeship participation tends to be highly gendered. In England, the largest apprenticeship sector, Health and Social Care, is over 80 per cent female, and dominated by older women, while Engineering is only 3 per cent female and dominated by younger men. With this in mind, and in order to explore relationships between age and gender, we completed five organisational case studies focussing on health, social care, engineering, hospitality and transport and one partial case study in constructioni. For practical reasons, and to comply with institutional ethics governance, we approached organisations and apprentices formally, via a range of networks and contacts. Once organisations had agreed to participate, we were given access to apprentices via their managers and trainers. This meant our selection was mediated by organisational gatekeepers. It also provoked some interesting discussion as to what could be categorised as 'adult/older', underscoring the prevailing ambivalence on age. Our final full sample consisted of 35 apprentices (14 women; 21 men) between their mid-twenties to early sixties. We also interviewed 28 managers and trainers to explore how age is managed in talk and practice. Reflecting the discussion above, and perhaps because they were training alongside young people, our research respondents in their twenties and thirties positioned themselves as 'adult', whilst those in their forties, fifties and sixties positioned themselves as 'old'. To pursue this paper's interest in older workers, we therefore concentrate on data generated by the 13 members of this latter group (see Table 1). Although this expands dominant, chronological definitions of older workers as those over 45 or 50 , our aim is to be sensitive to the self-identifications and lived experiences of the apprentices themselves (Riach, Rumens and Tyler 2014). While the sample size does not enable claims for validity, reliability or generalisability, our 
goal is for 'interpretive sufficiency' to allow the nuanced detail of lived experiences and organisational relations to be revealed (Amis and Silk 2008: 469).

Interviews were conducted 'on site' by members of the research team, usually in the premises where training was conducted; participants were given 'time out' to talk to us. Everyone was informed fully about the research aims before we asked for participation and informed consent. In the full case studies, we interviewed each apprentice twice, six months apart, to gain a sense of their experiences and how their apprenticeships were progressing over time. Interviews ranged between 20 minutes to an hour, with second interviews often longer due a relationship of trust being established. First interviews primarily focussed on biographies, decisions and motivations for training in older age, while second interviews probed for experiences of training, positive and negative. Commonality was achieved through use of openended topic guides based on the research questions outlined in the introduction but, as qualitative interviewers, we also sought to allow participants freedom to fashion their own stories (Lindebaum, Jordan and Morris 2015).

Interviews were recorded and transcribed, and submitted to close textual reading by all members of the team, coding each transcript by hand. The approach adopted was a hybrid of both directed and deductive (Stage 1) and inductive (Stage 2) thematic analysis (Fereday and Muir--Cochrane 2006). To answer our research questions, Stage 1 coded for all references to age, gender, motivations and barriers, benefits and challenges of being an older apprentice. Stage 2 consisted of rereading the data in a less preconceived way, looking very closely at the language for thematic patterns and regularities within and between the codes, with the aim of generating a theoretical framework through which to interpret our findings. Assumptions and theories were reflexively critiqued within the team. Three themes emerged from this 
study that we discuss in our analysis below. These coalesced around (i) how apprentices and managers/trainers positioned themselves in relation to the discursive landscape when talking about reasons for retraining at an older age. The ways in which their narratives either (ii) negated and/or (iii) confirmed the acceptability of 'a new start' highlighted personal and organisational attitudes and the careful negotiation these demanded. These themes resonated with Freeman's theoretical concepts of temporality, chrononormativity and transgression which we adopted as a valuable lens by which to analyse the findings.

\section{Findings}

\section{'My first thought was: "l'm too old"”}

Our participants' narratives of their transitions into apprenticeships at an older age, discussed in their first interviews, revealed the intricate interplay of dominant discourses of ageing with the alternative temporalities identified by Freeman (2010). Their stories exposed how the powerful impact of the past on the present and the competing drag of family temporalities had culminated now, at an older age, in occupational retraining. At the same time, a lingering sense of being 'too old' often cast a shadow over these ambitions. The accounts were highly gendered: for many of the women, motherhood and the demands of 'domestic time' had routinely ruptured the flow of their labour market participation, as work had had to accommodate family life:

I did the classic where you have children and it was not until 2010 that I decided to come back to work. I chose to work in this industry although no experience whatsoever! So when this came up I just grabbed the chance (Sonia, 50, Hospitality) 
At first it was the fact it was convenient, local, 2 minutes from home, 2 minutes from children. Initially, that was the reason why, just needed the job. It's only been this last year that I 've really thought I want something on my CV, to say l've done something in life. (Rachel, 42, Hospitality)

After years of putting the temporalities of family life first, many of the women expressed pleasure that they were now able to participate more fully in the labour market and receive training to develop more secure careers. For the men in our sample, apprenticeship also offered an opportunity to disrupt trajectories formed in the past and construct alternative identities. For example, at 48, Andy had come to a point in his life where he wanted to rectify his under-achievement at school and thirty years of low-paid, short-term jobs. From building, bus driving and gardening to painting, decorating and fitness-instructing, he had never had a secure wage:

I left school at 15: I was more concerned about looking after myself and getting a job because....it wasn't very secure. Back then I just done anything and everything, whatever, the money wasn't good at the time, I was doing loads of overtime and shift work and when you see the wages at the end of the week-oh I felt like crying! (Andy, 48, Construction)

The fact that Andy was now, in his late forties, training within a secure, 'gold standard' organisation was a source of great pride, by which regrets of past failures or time wasted could be supplemented with a new sense of achievement and selfworth.

Barry's training in social care also presented a route out of economic instability, caused by redundancy and unemployment. A former stand-up comedian, Barry had seen his career nosedive 'from having the phone ring off the hook, it was getting harder and harder'. Leaving 'show business' to pay for forklift truck training, 'as being 
older, the more I did for myself it would be easier to find a job and what better person to invest in than myself', his new career was, unfortunately, short-lived. He was soon made redundant and, talking things over with his wife and her sister who were both care assistants, he was persuaded to consider the vocation himself: 'They said: you'd be brilliant with your banter! My first question was would they accept a man? Anyway the first week I did 28 hours, the second 56 and it never stopped after that!' Derek, an apprentice engineer who had previously worked in administration within the Engineering case study, had also decided to forge a break with the past, having long felt being stuck in an office was just 'not him'. He had always been envious of the engineers who worked outdoors, constantly on the move, coming in at the end of the day with the rain on their jackets. After twenty years of watching them enviously, he applied for a transfer: his family were surprised, the demands of the training meaning that, 'I don't get there much, but they saw the change in me, they knew I was stressed and they said they can see I'm much happier'.

Although some participants had knowingly applied for their apprenticeship, others had applied for a job, only then to be told that they would be training as an 'apprentice' (Fuller and Unwin 2010). For some this was at first experienced as challenging. The discourse of ageing as decline and strong senses of chrononormativity infused the narratives of those with initial misgivings. Evelyn, an apprentice in social care, admitted that her early reluctance was due to a selfidentity, at 62, as 'I'm 'too old! But [the organisation] assured me I wasn't'. Similarly, Brenda, a Health Care apprentice, had also at first felt that she was too old. Throughout her adult life she had put her children first, working as a dinner lady and school cook, her self-confidence consistently undermined by her sense that she had 
underachieved at school. The thought of the apprenticeship resurfaced this long-held unconfident learner identity: 'I wasn't brainy enough to do it and I was too old ...'

It was not only the women who at first positioned themselves as too old for retraining. David had a background in sales and surveying before being made redundant. Social care had always been a lingering ambition, but as the years went by he felt his age meant that he had lost the chance:

Years and years ago, when I was about 30, I worked in selling and was looking to do something else and I looked at training to become an OT [Occupational Therapist]. A sequence of events got in the way, a marriage break-up, selling property and a business that didn't take off, but always in the back of my mind I periodically thought about, but I thought I was too old to do it, which I guess realistically I am, I wouldn't want to be starting a degree now, but the chance to be an assistant OT engaged me, really caught my imagination (David, 52 , Care)

Barry had also reacted with surprise when offered his apprenticeship, assuming that older age mitigated against the chance to train in a new career:

You get to a certain age and you get discarded, and then you've got to look at jobs where are they not bothered about how old I am, so you're going down the ladder... So when they first told me about the apprenticeship, I laughed, I smiled, 'cos at the time I was 48 , I said why are you speaking to me? And they said they weren't bothered about how old I was, I had experience... (Barry, 48, Care)

Further, it was clear that families and friends also played a key role in initially positioning some of the participants as 'past it'. Evelyn's children had scoffed, "' Oh mum! You're doing an apprenticeship! You're a bit old!" Because they're also of the 
opinion it's for a young person'. Likewise, Ruth, a social care apprentice, told us her children 'think it's hilarious, they think I'm far too old!'

For some, the decision to retrain was more imposed. In our Transport case study, apprenticeships were bound up with a broader corporate-wide initiative to upskill its older workers in technological skills following concerns that the organisation was outdated and uncompetitive. As Peter explains:

'I was told basically [to do the training]. I wasn't keen. I didn't see the point'...Being perfectly honest, I'm quite happy to stay where I am now. I'm 50. I've got a decent level of customer service skills and I'm quite happy with what I already know'. (Peter, 50, Transport)

While the organization's role within the retraining impetus was particularly evident for Transport's employees, it is clear that other forms of structural drivers underscored the 'choice' to retrain by many of the apprentices across the case study sites (Karpinska, Henkens and Schippers 2011).The mutuality of past and present subjectivities, and the search to disrupt historical constraints to remake new lives, exposed the filtering role played by the intersections of gender and class in accessing secure careers at the 'normal' time. As such, apprenticeships can offer an important route into more stable, fulfilling employment for those routinely disenfranchised from such opportunities. Nevertheless, hurdles created through negative self-images and the responses of family and friends to retraining 'out of step' were in some cases augmented by organisational affirmations of chrononormativity. 


\section{Reaffirming Organisational Chrononormativity.}

Older apprentices clearly have the potential to disrupt the chrononormativity of organisational life. Traditionally understood as young, inexperienced, untrammelled by family responsibilities and eager to learn from their elders (Akkerman and Bakker 2012), an apprentice who is older, perhaps with previous qualifications, several careers behind them and caring responsibilities can present a powerful contradiction to normative expectations. Our second interviews with our participants and those with managers identified two key responses to this challenge: to ignore age diversity; or contest it. While different in form and consequence, both responses attempted to reaffirm chrononomativity as the underpinning logic of organisational life.

The primary response, from both managers and trainers, was to attempt to ignore differences in age and treat everyone as if they are 'young' and living life '(chrono) normally'. This was particularly the case at Engineering. Here apprenticeship starts with an extended period of residential training, forming a key mechanism by which new recruits are socialised into the organisation. Over their first year, they spend much of their time at a Training Centre located in the heart of the countryside, living in all week, away from family and other distractions. This is a universalistic 'one size fits all' model, based on the assumption that apprentices are young, not used to looking after themselves and without family responsibilities. As the training coordinator Monica explains:

I book all the accommodation, irrespective of the age... so if they're a 40-year-old, he's included as much as the 16 year olds. They are looked after very well. It's quite paternalistic, and I mean that in a nice way. I think for me though there is a strange dichotomy in the way they treat the apprentices. The eldest is 40 , and the younger is 16 . But I don't think they've got to grips with the fact that few are 16 ! Inviting them to the 
Sunday 'Family Day'- it's a bit odd as you assume it's their parents who come...(laughing) but some of them are old enough to have a family!

It was also clear from our conversations with trainers that the apprentices' previous work experiences and qualifications were not always valued, perceived as bringing attitudes and skill performances which may contradict the organisational habitus and make them less compliant (Zanoni 2011). Again, this was particularly the case in Engineering and Construction: while both organisations are active in recruiting adult apprentices to fill skills gaps, it was felt to be 'more productive' to ignore age and position everyone as if at the start of their careers:

One of the challenges is that they've good and bad past experience, and sometimes it's difficult to change. I tend to think that by putting them through the programme from start to finish, it's much easier to shift thinking and behaviours (Bob, Trainer, Engineering)

A further concern was that the older workers do not disrupt existing social structures and relations. When Derek was accepted onto the Engineering programme, Monica felt it necessary to advise him on his performance of age:

It was funny, when he first came I sort of had a word with him to say "you do stand out in the group". We were conscious we didn't want him to become the father figure, it wouldn't have been fair to him. He was fine, he's been very supportive of the younger ones, but he doesn't try and push himself, he's been really good, he's quite a quiet bloke. Not sort of pushy. I think he's coping well.

'Not pushing' themselves: in other words, agreeing to suppress previous experiences and even age-normative performances of age, was not always appreciated by the apprentices, who felt that systematic simplicity was sometimes prioritised over acknowledgement of diversity and acceptance of different lifestyles. This was also 
demonstrated by the fact that little accommodation may be given for an older applicant's lack of skills due to cohort factors. For example, in order to be accepted onto an apprenticeship, Brenda, a Healthcare apprentice, like all applicants, had to pass entrance exams in English and Maths. These were subjects she had failed at in school and, even worse, the exams were taken online. Brenda had never learnt to use a computer: 'I could play solitaire and that was it!

I had this opportunity and I just thought I was going to do it. But the functional skills, the numeracy and English: it was hair-raising! I remember thinking "how am I going to put a graph on here?" We've a computer at home, but I never had access to it. I've got three children that take over. I said to my son "I can't do it!" He said, "I'll help you". He bought me books for primary school children and I learnt from there. Even adding up is different now! I sat for hours learning how to use a computer. The first exam, she said "you do Word?" and I texted my son, "what is this?!" Never done Word before, never done copy and paste, my son taught me it all. Children grow up almost from birth on the computer, I had no knowledge of it, no understanding. (Brenda, 50, Health)

Clearly, employees without technological skills can present problems for contemporary organisational processes but, rather than meeting this need with training provision, Brenda was left to resolve this at an individual level; an experience shared by others across the case study sites.

A second organisational response was to contest older age as a feasible stage of the lifecourse for training. Brenda, for example, was unsupported and even bullied by her manager, mocked for doing an apprenticeship 'at her age' (50). Refusing to play her part in Brenda's assessment, professing she was 'too busy', her manager reprimanded Brenda publicly, claiming that her doing an apprenticeship was 'a waste 
of time'. Thus, Brenda almost 'pulled out because she refused to do anything. I was being bullied, she was pushing me around, and I said "that's it, I'm not doing it!"'

Brenda's insecurity about her lack of formal educational qualifications, combined with the chrononormative assumptions made by her manager, consistently challenged her ability to construct a coherent and sustainable identity as an older learner. Derek, the Engineering apprentice, could counter rather more robustly the initial contestation of his presence on the Engineering apprenticeship. He quickly became aware that he needed to engage in some pretty sure-footed 'identity work' at the beginning of his training to demonstrate to his younger colleagues how he understood his age:

When I first started there were some raised eyebrows, "what's this old fella doing here?" I'm old enough to be their dads, some of them, but there's no malice in it. I think they thought I was the supervisor at first, but I explained that yeah l'd worked for so many years and l'd got aspects of knowledge from that, but as far as this apprenticeship was concerned I was starting from exactly the same point as anyone else. So I said that several times. I think that's settled now.

To be accepted as 'one of them', the chrononormativity of organisational life behoved Derek to deny that his previous experience may have value for his current training. Derek had to learn how to manage and perform being 'old' amongst much younger classmates: that yes, he was knowledgeable about some (other) things, but not about the learning relating to the apprenticeship. Yet while chrononormativity certainly acted as a spectre at the older apprenticeship feast, resistance and transgression was still possible. 


\section{Transgressing chrononormativity?}

Foucault (1982) argued that any form of 'conduct of conducts', that is, governance by transference of responsibility for conduct onto the individual, always introduces the possibility of counter-conduct: transgressions of dominant discourses and alternative performances (Moulaert and Biggs 2012). Once on the apprenticeship, many of our participants found the experience enabled a new positive sense of identity, achievement and self-worth, which, in turn, opened possibilities for non-normative performances of older age. Evelyn (62, Care) proudly explains:

I am so pleased, because I truly believe I would still be out of work. I had applied for quite a few vacancies and had managed to get two or three interviews, even though I was the age I was, and I thought, 'this is alright!' but I didn't get the job. So I thought, yes it's my age, it's putting them off. So when I was put onto the apprenticeship, I thought 'I'm worth something!' Because it boosts your morale, it doesn't make you feel like you're out to wash, sitting at home watching daytime telly, because that really drags you down.

Indeed, it was clear that others also relished the opportunity of reinventing themselves through upskilling. Any discomfiture that this might be at 'the wrong time of life' was offset by substantial personal benefits gained through the work itself, as Barry found from his social care apprenticeship: 'The way it is here, they don't look down their nose at you because you're a support worker, when you walk through that door, from the moment you walk in, you're treated with dignity and respect'. 'Mature selves' were regularly constructed in more positive terms than their younger ones, countering normative discourses of age as decline:

I love being with people, sometimes I give too much, I know that, but I can't change, what I give out I get back, so that's why this industry is tailor-made for me and if I'd 
known that when I left school I might have done it then...I'm more myself than I have been for a long time, especially if you spoke to friends who know me from when I was [younger], and my mum, she'd tell you that I'm more myself now than I have been for 20 years. Because l've got the freedom to be so and this has just made me, it's amplified, because I'm me so often (Sonia, 50, Hospitality)

In Brenda's case, her training gave her confidence to resist her manager's bullying and position herself more powerfully:

It's bringing my confidence out, I'm really able to stand up for myself more: "I've read about this so I know this is right", yeah, yeah! People on the unit were pushing me around a bit, and l've started to say "hang on a minute, this isn't in the paperwork, you're now allowed to do this!" It's made me stand up.

It was not only the apprentices who experienced benefits through transgressions of chrononormativity. Many of the trainers and managers spoke positively of the older trainees, seeing them as peers rather than pupils. This adjustment in power relations between learner and trainer was particularly evident in the classroom, where the older apprentices, far from being positioned traditionally, as unknowing and unworldly, were aligned with more positive qualities, such as learning quickly, enthusiasm and good time management. As an Engineering trainer summarised: 'the mature apprentice can drag the whole group up'. Older apprentices were also constructed as positive in 'business case' terms by managers who, through such tropes of 'maturity' 'reliability' and 'knowledge' perceived that older workers bring real value to organisations:

The business case essentially boils down to the highly motivated, enthusiastic, wellorientated individuals. Analysis shows time to market, to productive time, is 20 per cent 
quicker than the graduate entry. Once they come out of their training, they actually hit - and they're loyal - the retention rate is higher (Toby, Head of Skills, Engineering)

Both Health and Social Care, struggling with high turnover and the pressures of delivering a critical service, saw particular benefits from older workers, who may be on their:

Second or third career choice - and have come later into this. They bring a lot of life experience, a lot of them have looked after elderly relatives, children or been carers at home- they just haven't been able to come and do this kind of job before (Jill, Apprentice Manager, Health)

I genuinely think, the older age group, they've got life experiences, but they use those rather than be spoon-fed as soon as they see a spot of blood, or mopped up sick...they've got their life skills, they tend to be more devoted to study, they do come with more baggage, divorces, ill health, and they have all those things to contend with, but they still get through course. (Shirley, HR, Health)

As noted above, Transport's decision to retrain its older employees via apprenticeships emerged from skill needs and pressures to update for economic competitiveness, bolstered by a strong union presence which mitigated against redundancies and lay-offs:

We realised the organisation was very top heavy with older workers, who'd been with us 20-25 years and when they joined they didn't need qualifications, it wasn't that kind of organisation. Ten years ago we realised the world is changing quite dramatically. Them 25 years meant nothing if you didn't have qualifications to back that up. Staff didn't have basic English, maths and ICT- the building blocks if we were to gain improvement in service (Chris, HR) 
As was also the case in Health and Social Care, Transport had to do some quite 'heavy lifting' to convince some older workers to retrain:

We do have every now and then an individual who you can see just wants to do their job, come to work, get paid and go home. With those individuals, we're quite fortunate, cos our tutors are quite infectious, spreading the learning bug. We're lucky with our union learning reps, they're very persistent, the likes of Liz, she understands learning and the reasons behind it, she can see the benefits, she's an older worker herself and by having people like that it kind of helps dispel the myths.

Yet while some organisations are clearly recognising that there is a sound economic case for transgressing chrononormativity by retraining older workers, there is still a risk that age is reproduced in stereotypical ways. This is a theme we now turn to in our discussion of the implications of these findings for older workers.

\section{Discussion}

Our examination of the management and experiences of older apprentices has revealed a mixed and complex picture. On the one hand, our findings are somewhat pessimistic, suggesting that undertaking vocational training in older age has a considerable way to go before being accepted as 'normal' in organisational life. Our exploration of our participants' experiences has revealed that the discourse of 'ageing as decline' continues to act as a powerful and persistent counter to discourses of ageing productively and transgressions of chrononormativity. This enduring pervasiveness of chrononormativity within work and organisational processes constrains the subject positions open to older workers. A key consequence amongst our case study organisations was that past histories, previous qualifications and family responsibilities were often misrecognised or denied as 
having accumulated value (Skeggs 2011), in favour of inflexible training principles established under 'the youthful apprentice' model. As our Engineering case study most clearly demonstrated, supporting findings by Zanoni (2011), age 'difference' may be feared as bringing attitudes and skill performances which might disrupt the smoothness of the organisational habitus. A simultaneous finding however was the expectation that would-be apprentices should have certain skills, such as digital literacy; skills which older workers may not necessarily have. Chrononormativity dictates that little is put in place for this: the bald message for many is, if you want to do an apprenticeship, it is up to you to acquire the relevant computer skills, as well as refresh functional skills.

The chrononormativity of work and organisational settings thus required many of our participants to actively negotiate the terms of their existence on an individual basis to construct a subjectivity that was 'viable' to their peers and managers (Riach, Rumens and Tyler 2014). Derek, for example, worked hard to become 'one of the lads', while Brenda had a tougher challenge convincing her manager of her right to train at an older age. Brenda's lack of support may be explained in part by the intense pressures of the health care sector (Ogińska-Bulik 2006), but contestation of older age as a viable subjectivity for training has been found to be especially apposite for women (Hodges 2012; Yerkes 2010).

However, on the other hand, a more positive picture emerges. Our research also revealed that the relationship between employers and older workers is both complex and contradictory (Martin et al 2014), and that a benefit of retraining in older age is empowerment. In Brenda's case, her new-found knowledge and sense of identity, supported by her trainers, eventually gave her the confidence to resist her boss's attempts to disaffirm her. Others also demonstrated real pride in what they had 
achieved and become through their training: enjoying, in Evelyn's case a regained sense of self-worth; realising, in Barry's case, how very good he was at caring or, in David and Natalie's case, a lifelong ambition to work in healthcare; or even, in Derek and Sonia's case, discovering the ability to be 'me'. As Biggs (2004) argues, it is through such performative aspects of identity that creativity and transgressive freedoms are produced, and 'personal identity can be celebrated in an act of reflexive self-creation' ( $p 49)$.

Training can thus offer an important second chance to older workers who may have been marginalised and excluded from educational and labour market rewards at a younger age. It was clear that many of our participants had previous histories of fractured work, their trajectories shaped by the powerful effects of the gendered and classed structures of education and work within the United Kingdom (Atkinson, Roberts and Savage 2012; Bradley and van Hoof 2005; Moore 2009). While underachievement at school was common across the narratives, for some women, their capacity to make choices about their working lives were further intersected by the expensive costs of privatized childcare in the UK (Del Boca et al 2006), which determine that periods of not working, or working part-time, are recurrent features of many mother's lives (Grant, Yeandle and Buckner 2006).Training in later life can thus offer 'a new start' for those with non-standardised non-chronometric pasts: once on a programme, perhaps having overcome a personal subjectivity of being 'too old' to begin a new career or train anew, particularly if this involved formal learning and study of functional skills, most gained a new sense of the self as 'capable' (Pietilla and Ojala 2011). Their talk reflected the discourse of ageing productively but it was clear that this involved more than economic security alone: the apprenticeship initiative also offered the opportunity of reinventing themselves through upskilling, 
and many of our participants found themselves keen to learn and enjoying retraining (Ainsworth and Hardy 2008).In some cases, underscoring still further the significance of structural drivers (Vickerstaff 2010), the impetus to retrain older workers was seen as crucial by some of our organisations, such Transport, Care and Health. Martin et al (2014) note how, in many global contexts, contemporary workplaces are facing two crucial facts: an ageing workforce and the need for ongoing training to maintain productivity. This means that growing numbers of workers are falling into new kinds of non-standard work arrangements outside of linear career paths, even within the same organisation or profession. Yet while Martin et al (2014) still found a general reluctance to train people in their 50 s and 60 s within their Australian-based study (see also Felstead 2010), our findings indicate a rather more positive picture. Confirming recent policy discourses (Age Positive 2015), senior managers across the case study sites were becoming convinced of the economic benefits of training older people, while trainers, were impressed by the teaching and learning benefits of intergenerational classrooms (Gerpott, Lehmann-Willenbrock and Voelpel 2016; Ropes. 2013; Tempest, 2003). While younger apprentices can learn from the oftdemonstrated highly motivated attitudes to learning of older trainees, older learners can draw from the more contemporary knowledge and skillsets of younger colleagues. Indeed, given the findings of general reluctance by those over 50 to undertake further training, it may be the case, as in Transport, that it is the organisation which should be the driving agent in rebutting the social stereotypes about ageing workers and developing new understandings and contexts in terms of older workers' performances, productivity and learning abilities. Yet while some organisations recognise the sound business case for transgressing chrononormativity, the contradictions which exist in meanings of older age (Lyon and 
Glover 1998) mean there is still a risk that 'old' is reproduced in stereotypical ways. 'Older worker' can become a trope for, on the one hand, as demonstrated by Engineering, a particular 'ideal type' of employee, linked to a narrow range of qualities such as loyalty, maturity and responsibility but also, on the other, as revealed by Transport, conflated with a slow and resistant approach to learning. As we now turn to conclude, this requires careful management.

\section{Conclusion}

Our study of older apprentices offers a useful heuristic device by which to develop understanding of the ways in which older age is understood, experienced, performed and managed within organisations, not only within England, but in other neoliberal economies facing similar demographic changes. Four aspects emerge as key. First, as mentioned above, is the enduring purchase of social structure to experiences of age and ageing within work and organisations, an aspect all too regularly elided in policy discourses. While research is increasingly responding to calls to recognise the fundamentals of gender to ageing (Tretheway 2001), our findings reemphasise how this operates in intersection with social class and educational background. Retraining as an adult is often contingently produced from previous disadvantage (Gilleard and Higgs 2005) yet, rather than offering compensation and support for a 'new start', this may, if mismanaged by organisations, serve only to introduce or even amplify further inequalities. Unless the diversities of age and ageing by those pursuing nonstandard pathways are recognised and accommodated, the opportunities offered through adult apprenticeships cannot be fully realised (Brooke and Taylor 2005).

Second, Freeman's concept of chrononormativity has provided a productive framework by which to analyse older workers' biographies, organisational processes 
and the management of older-age training. The temporal approach helps to 'deliberately reveal, challenge and subvert the smooth production of the normal and natural in organisational life' (Riach and Kelly 2015: 288) by exposing how dominant understandings of age position people as 'old'. At the same time, the alternative temporalities framing everyday lives mean that people arrive at the point of being judged as 'old' with very different biographies behind them: some never having had the opportunity to construct careers they wanted 'at the right time'. For these people, training 'out of step' may be their first bite at the cherry. This underscores the need for age norms governing organisational practices keeping pace with the conceptual policy shift to revision ageing, training and work as 'without borders'.

Third, and in relation to this, extending Freeman's (2010) critique of chrononormativity and the recognition of alternative temporalities to older workers also helps to reveal the multifaceted and complex concatenation of the age/training relationship. Attending to the multiple temporalities of people's lives offers a lens to the intricate confluence of identity, experience, emotion and social relations which constitute age, yet can be fissured by the chrononormativity of organisational processes. Our findings suggest that succeeding as an older apprentice may require sublimation of age and the past: other selves and competing temporalities removed from the organisational gaze. The apprentices' narratives reveal the symbolic violence of such governance (Bourdieu and Wacquant 1992). Their stories demand creative rethinking of how to manage training 'out of joint'.

Fourth, the 'normative gap' between policy and practice (Blatterer 2010:65) means that at present the onus is largely on those individuals who disrupt chrononormativity to negotiate an identity with peers and trainers for themselves, in the process remaking what it means to be 'older' within organisational life. To address this, our 
conclusions suggest some clear practical implications for organisations developing training for older workers (Fuller et al 2015). At the very least, all those involved in selecting and training apprentices should be trained in age/ diversity awareness and unconscious bias (Lyon and Glover 1998). Second, previous experience should be recognised and valued and, third, systems and processes should enable widened participation and recognise diverse lifestyles and responsibilities. Importantly however, across the case study sites, there is encouraging evidence of trainers and managers recognising the value of older apprentices. Albeit that this sometimes tended to be in stereotypical ways, and as such there is still some way to go before chrononormative standards are properly countered, this is nevertheless a positive step towards producing age-diverse workplaces. These conclusions are not only important for the English context, but have broader resonance for other economies considering expanding their apprenticeship and training programmes to older workers.

\footnotetext{
i 'Official statistics on apprenticeship in England are available at :https://www.gov.uk/government/statistical-data-sets/fe-data-library-apprenticeships.'

ii We conducted some additional interviews in Construction due to late access to the Case Study. This included an interview with an older apprentice.
}

\section{References}

Adam, B. 1995 Timewatch: The Social Analysis of Time Polity, Oxford Age Positive 2015 Employing older workers: an employer's guide to today's multigenerational workforce HMSO, London

Ainley, P. and Rainbird, H.1999 (Eds) Apprenticeship: Towards a New Paradigm of Learning Kogan Page, London:.

Ainsworth, S. and Cutcher, L. 2008 Staging value and older women workers: when' something more' is too much Int. J. Work Organization and Emotion 2, 4, 334-57 
Ainsworth, S. and Hardy, C. 2008 The Enterprising Self: An Unsuitable Job for an Older Worker Organization 15,3, 389-405

Akkerman, S. and Bakker, A. 2012 Crossing Boundaries Between School and Work During Apprenticeships Vocations and Learning 5, 2, 153-73

Amin, K. 2015 Temporality Transgender Studies Quarterly 2, 4, 219-21

Amis, J. and Silk, M. 2008 The philosophy and politics of quality in qualitative organizational research Organizational Research Methods 11,3, 456-80.

Atkinson, W. Roberts, S. and Savage, M. 2012 Class Inequality in Austerity Britain: power, Difference and Suffering Palgrave, London

Aubert, P., Caroli, E. and Roger, M. 2006 New Technologies, Organization and Age: Firm-Level Evidence The Economic Journal 116, F73-93

Baily, C. 2009 Reverse intergenerational learning: A missed opportunity? Al \& Society, 23, 111-115.

Barrett, A. 2005 Gendered experiences in mid-life: Implications for age identity Journal of Aging Studies 19:163-83

Baxter, J. 2003 Positioning Gender in Discourse Palgrave, Basingstoke

Biggs, S. 2004 Age, gender, narratives and masquerades Journal of Aging Studies 18: $45-58$

Blatterer, H. 2007 Coming of Age in Times of Uncertainty Berghahn Books, Oxford, Boudiny, K. 2013 'Active ageing': from empty rhetoric to effective policy tool' Ageing and Society 33,6, 1077-98

Bourdieu, P., \& Wacquant, L.1992 An invitation to reflexive sociology Polity Press, Cambridge:

Bradley, H. and Van Hoof, J. .2005 Young People in Europe: Labour Markets and Citizenship Polity Press, Cambridge:. 
Brooke, L. and Taylor, P. 2005 Older workers and employment: managing age relations Ageing and Society 25. 3, 415-29

Chou, R. and Choi, N. 2011 Prevalence and correlates of perceived workplace discrimination among older workers in the United States of America Ageing and Society 31, 6, 1051-70

Del Boca, D. and Locatelli, M. 2006 The determinants of motherhood and work status: a survey, IZA Discussion Papers, No. 2414, http://nbnresolving. de/urn:nbn:de:101:1-20090309147

DfES (2003) 21st Century Skills: Realising our potential Cm.5810, HMSO, London.

Fereday, J. \& Muir--Cochrane, E. 2006 Demonstrating rigor using thematic analysis: A hybrid approach of inductive and deductive coding and theme development. International Journal of Qualitative Methods, 5,1, 80-92

Felstead, A. 2010 'The importance of "teaching old dogs new tricks": training and learning opportunities for older workers'. In Parry, E and Tyson, S (eds) Managing an AgeDiverse Workforce, Palgrave, London

Field, J., Burke, R.J. and Cooper, C.L. 2013 (Eds) The SAGE Handbook of Ageing, Work and Society, Sage, London:

Freeman, E. 2010 Time binds: Queer temporalities, queer histories.: Duke University Press, Durham, NC

Foucault, M. 1980 Power/Knowledge Harvester Press, Brighton

Foucault, M. 1982 Afterword. The subject and power. In Dreyfus, H. and Rabinow P. (Eds) Michel Foucault: Beyond Structuralism and Hermeneutics Harvester Press, Brighton 208-26 
Foweraker, B. and Cutcher, L. 2015 Work, Age and Other Drugs: Exploring the Intersection of Age and Masculinity in a Pharmaceutical Organization Gender, Work and Organization 22, 5, 459-473

Fuller, A. and Unwin, L. 2003 Creating a 'Modern Apprenticeship': a critique of the UK's multi-sector, social inclusion approach, Journal of Education and Work 16, 1, 5-25.

Fuller, A. and Unwin, L. 2009 Change and Continuity in Apprenticeship: the resilience of a model of learning. Journal of Education and Work 22, 5, 405-416. (doi:10.1080/13639080903454043).

Fuller, A. and Unwin, L. (2013) Contemporary Apprenticeship: International Perspectives on an Evolving Model of Learning Routledge, London

Fuller, A., Heath, S. and Johnston, B. 2011 (Eds) Rethinking widening participation in Higher Education: The role of social networks, Routledge, London:

Fuller, A., Leonard, P. Unwin, L. and Davey, G. 2015 Does apprenticeship work for adults? The experiences of adult apprentices in England. UCL, London

Gerpott, F. H., Lehmann-Willenbrock, N. \& Voelpel, S. C. 2016. A phase model of intergenerational learning in organizations. Academy of Management Learning \& Education (Early view)

Gilleard C. and Higgs, P. 2005 Contexts of ageing: Class, cohort and community Polity Press, Malden, MA

Gov.UK 2016 Apprenticeships geography, equality and diversity and sector subject area: starts 2002/03 to 2015/16 available at https://www.gov.uk/government/statistical-data-sets/fe-data-library-apprenticeships, accessed $6^{\text {th }}$ Oct 2016 
Grant, L. Yeandle, S. and Buckner, L. (2006) Working below potential: women and part-time work: synthesis report, GELLM Series 2 Part 2, Centre for Social Inclusion, Sheffield Hallam University, Sheffield

Gulette, M.M. 2004 Aged by Culture University of Chicago Press, Chicago

Halford, S. and Leonard, P. 2006 Negotiating Gendered Identities at Work: Place, Space and Time Palgrave, Basingstoke

Hodges, J. 2012 The transition of midlife women from organizational into selfemployment Gender in Management: An International Journal 27, 3, 186-202

Ibarra, H. and Barbalescu, R. 2010 Identity as narrative: prevalence, effectiveness, and consequences of narrative identity work in macro-work role transitions, Academy of Management Review 35, 1, 135-154.

Karmel, T. 2006 Older workers in apprenticeships and traineeships National Centre for Vocational Educational Research, Australia

Karpinska, K. Henkens, K. and Schippers, J. 2011 The recruitment of early retirees: a vignette study of the factors that affect managers' decisions Ageing and Society 31, 4, 570-89

Keep, E., Mayhew, K. and Payne, J. 2006 From skills revolution to productivity miracle: not as easy as it sounds? Oxford Review of Economic Policy 22, 4, 539-59

Leitch, S. 2006 Leitch Review of Skills Stationery Office, London

Lindebaum, D., Jordan, P. and Morris, L. 2015 Symmetrical and asymmetrical outcomes of leader anger expression: A qualitative study of army personnel Human Relations (early view) 
Lorreto, W. and White, P. 2006 Employers' attitudes, practices and policies towards older workers, Human Resources Management Journal, 16, 3, 313-30.

Loretto, W. Vickerstaff, S. and White, P. 2007 The Future for Older Workers Policy Press, Bristol

Lyon, P. and Glover, I. 1998 Divestment or investment? The contradictions of HRM in relation to older employees, Human Resource Management Journal, 8, 1, 56-66.

Martin, G., Dymock, D., Billett, S. and Johnson, G. 2014 In the name of meritocracy: managers' perceptions of policies and practices for training older workers Ageing and Society 34, 6, 992-1018.

McNair, S. Maltby, T. and Nettleship, S. 2007 Age Training and Employment: A Review of the Literature. Centre for Research into the Older Workforce, NIACE. Leicester, U.K.

Moore, S. 2009 'No matter what I did I would still end up in the same position: age as a factor defining older women's experience of labour market participation' Work, Employment and Society 23, 4, 655-71

Moulaert, T. and Biggs, S. 2012 International and European policy on work and retirement: reinventing critical perspectives on active ageing and mature subjectivity Human Relations 66,1, 23-43

Ng, T.W.H. and Feldman, D.C. 2012 Evaluating six common stereotypes about older workers with meta-analytical data' Personnel Psychology 65, 4, 821-58

OECD 2013 Skilled for Life? Key findings from the Survey of Adult Skills OECD, Paris:

Odih, P. 1999 Gendered time in the age of deconstruction Time and Society 8, 1, 938 
Ogińska-Bulik, N. 2006 Occupational stress and its consequences in healthcare professionals International Journal of Occupational Medicine and Environmental Health 19, 2, 113-22

Pietilä, I. and Ojala, H. 2011 Acting age in the context of health: Middle-aged working class men talking about bodies and aging Journal of Aging Studies 25, 380-89

Radl, J. 2012 Too old to work, or too young to retire? The pervasiveness of age norms in Western Europe, Work, Employment and Society, 26, 5, 755-771.

Ranzijn, R. 2010Another Way to Oppress Marginalized and Disadvantaged Elders? Journal of Health Psychology 15, 5, 716-23

Rauner, F. and Smith, E. (Eds) 2009 Rediscovering Apprenticeships Springer, Dordrecht.

Riach, K. and Cutcher, L. 2014 Built to last: ageing, class and the masculine body in a UK hedge fund Work, employment and society 28, 5, 771-787

Riach, K. and Kelly, S. 2015 The need for fresh blood: Understanding organizational age inequality through a vampiric lens Organization 22, 3, 287-305

Riach, K. Rumens, N. and Tyler, M. 2014 Un/doing Chrononormativity: Negotiating Ageing, Gender and Sexuality in Organizational Life Organization Studies 35,11,1677-98

Ropes, D. 2013. Intergenerational learning in organizations. European Journal of Training and Development, 37, 713-727.

Ropes, D., \& Ypsilanti, A. 2012. Factors influencing intergenerational learning: Towards a framework for organisations to ensure successful learning in older employees. In European Centre for the Development of Vocational Training (Ed.), Working and aging. The benefits of investing in an aging workforce: 280-307. European Union, Luxembourg 
Rudman, D. 2006 Shaping the active, autonomous and responsible modern retiree: an analysis of discursive technologies and their links with neo-liberal political rationality Ageing and Society 26, 2,181-201

Sennett, R. 2006 The Culture of New Capitalism Yale University Press, New Haven SFA/BIS (2016) Further Education and Skills, Statistical First Release SFA/SFR 33, https://www.gov.uk/government/uploads/system/uploads/attachment data/file/51385 1/SFR commentary March 2016 QAR Update.pdf

Simpson, M., Richardson, M. and Zorn, T. 2012 A job, a dream or a trap? Multiple meanings for encore careers Work, Employment and Society 26,3, 429-46

Skeggs, B. 2011 Imagining personhood differently: person value and autonomist working class value practices Sociological Review 59, 3, 496-513

Standing, G. 2011 The Precariat: The New Dangerous Class Bloomsbury, London Tempest, S. 2003 Intergenerational Learning. A reciprocal knowledge development process that challenges the language of learning Management Learning 34, 181200.

Thomas, R. Hardy, C. Cutcher, L. and Ainsworth, S. 2014 What's Age Got to Do with It? The Critical Analysis of Age and Organizations Organization Studies 35, 11, 1569-84

Tretheway, A. 2001 Reproducing and Resisting the Master Narrative of Decline: Midlife Professional Women's Experiences of Aging Management Communication Quarterly 15, 2, 183-226

Unwin, L., Davey, G., Fuller, A. and Leonard, P. 2015 Supporting an Ageing Workforce: Implications for Working Life, Training and Skills Policy in England - A Literature Review, LLAKES Research Paper 51, UCL Institute of Education London. Vickerstaff, S. 2010 Older Workers: The 'Unavoidable Obligation' of Extending Our Working Lives? Sociology Compass, 4,10, 869-79. 
Walker, A. and Maltby, T. 2012 Active ageing: A strategic policy solution to demographic ageing in the European Union, International Journal of Social Welfare, 21, 1, 117-130.

WHO 2002 Active Ageing: A Policy Framework World Health Organization, Geneva:

Yerkes, M. 2010 Diversity in Work: The heterogeneity of Women's Employment Patterns Gender, Work and Organization 17, 6, 696-720

Zanoni, P. 2011 Diversity in the lean automobile factory: doing class through gender, disability and age Organization 18,1,105-27 